\title{
DISTRIBUTION AND ECOLOGY OF GAMMARUS TIGRINUS SEXTON, 1939 AND SOME OTHER AMPHIPOD CRUSTACEA NEAR BEAUFORT (NORTH CAROLINA, U.S.A.)
}

\author{
by \\ MARION J. VAN MAREN \\ Institute of Taxonomic Zoology, University of Amsterdam, The Netherlands
}

$\&$

Duke University Marine Laboratory, Beaufort, North Carolina, U.S.A.

\section{SUMMARY}

During summer 1977 the distribution and ecology of amphipod Crustacea in the coastal plain of north Canolina were studied. Ecological data were collected in particular on Gammarus tigrinus, a North American species, which has been introduced in western Europe. The present gammarid, able to endure high water temperatures and adapted to a wide variety of salinities, is found in the more upstream parts of the estuaries in North Carolina. More downstream, at higher salinities, it is replaced by Gammarus palustris, while at very low salinities or in fresh water Gammarus fasciatus is commonly met.

Moreover, some data are given on the distribution and ecology of several other amphipod species in the Beaufort region.

\section{RESUME}

Pendant l'été 1977 la répartition écologique de Crustacés amphipodes a été étudiée dans la plaine littorale de Caroline du Nord. Des observations furent effectuées en particulier sur l'écologie de Gammarus tigrinus, espèce nord-américaine introduite en Europe. Ce Gammare, capable de résister à des températures élevées et adapté à des salinités très variables, est trouvé dans les parties plus en amont des estuaires de Caroline du Nord. Plus en aval, dans les eaux méso- et polyhalines, Gammarus tigrinus est remplacé par Gammarus palustris, tandis que dans les eaux douces et oligohalines Gammarus fasciatus est couramment rencontré.

En plus, cette étude a fourni des données sur la répartition et l'écologie de plusieurs autres espèces d'Amphipodes dans la région de Beaufort.

\section{INTRODUCTION}

During summer 1977 the distribution and ecology of amphipod crustaceans was investigated in the coastal plain of North Carolina. The present study was carried out during a stay at the Duke University Marine Laboratory at Beaufort. Amphipod samples were taken in estuaries and freshwater biotopes in the Beaufort region to collect data on the ecology of Gammarus tigrinus in particular. This species, originally inhabiting the eastern coast of North America, has at some time been introduced in western Europe and was first described from England by Sexton (1939). Gammarus tigrinus has rapidly invaded nearly all oligohaline waters in the Netherlands, competing successfully with the indigenous gammarid species. Its range extension, still proceeding, has been surveyed by members of the Institute of Taxonomic Zoology of the University of Amsterdam, resulting in a series of publications (Nijssen \& Stock, 1966; Pinkster \& Stock, 1967; Dennert et al., 1968; Gras, 1971; Smit, 1974; Pinkster, 1975; Dieleman \& Pinkster, 1977).

\section{STUDY AREA AND METHODS}

The small town of Beaufort, situated on a tongue of mainland, is separated by water from the sandy offshore bank, known as Shackleford Bank. Access to the open ocean is gained by the Beaufort Inlet. The various waterways, which communicate directly or indirectly with Beaufort, are very complicated in shape and contain a large number of shoals, banks and islands.

While offering a variety of sandy and muddy substrates, no true natural rocks are found in the Beaufort region. Hard substrates are formed by jetties, sea walls, pilings, oyster shells and by miscellaneous man-made objects (bottles, beer cans, etc.). The coastal area of the mainland is characterized by extensive Spartina marshes. The mean tidal range is $0.75 \mathrm{~m}$ (about $0.9 \mathrm{~m}$ for spring tides).

The estuary of the Newport River ${ }^{1}$ ), a wide

1) Irrespective of the salinity or current, the water types in the area are locally called "rivers". 
bay with polyhaline salinities, is connected by the Adam Creek Canal with the Neuse River. In summer, the freshwater supply of the latter is low to such an extent that marine influences are still measurable as far as New Bern, a town situated at almost $100 \mathrm{~km}$ from where the Neuse River discharges into the Pamlico Sound.

The vegetation of the river swamps of the coastal plain is characterized by the River-cypress (Taxodium distichum), growing in shallow water, often over a calcareous subsoil. This tree has a trunk gradually tapering near the base and root formations, which often provide the only hard substrate in the more upstream parts of the North Carolina estuaries.

Sampling of the amphipods was carried out with a dip net. As far as temperature readings have been made, a mercury thermometer was used (scale in $0.1^{\circ} \mathrm{C}$ ). Salinities were measured with the aid of a refractometer. The $\mathrm{pH}$ was determined with a $\mathrm{pH}$ meter "Leeds \& Northrop".

The animals were fixed in $4 \%$ formaldehyde and preserved in $70 \%$ ethanol.

In appendix II the position of the sampling stations, visited during the present study, is given.

\section{RESULTS}

Fig. 1 shows the names of the amphipod species sampled at different localities in the estuary of the Neuse River, as well as the salinities measured at these stations. Near the bridge on highway 43 , S.W. of Askin, gammarids still occurred, but more upstream, near Kinston, none have been found. The great majority of the Neuse River stations presented a sandy substrate. Only in those places where some hard substrate was available (mostly provided by the roots of the River-cypress) gammaridean Amphipoda were captured in the wavewashed zone of the river.

The temperature of the water varied from $18.5^{\circ} \mathrm{C}$ in May to $34^{\circ} \mathrm{C}$ in August, while the $\mathrm{pH}-$ range was 6.3-7.3.

Both stations sampled in the Trent River, a tributary of the Neuse River, yielded Gammarus tigrinus Sexton, 1939 (salinities 1 and 2\% Substrate, temperatures and $\mathrm{pH}$ in this stream resemble to a large degree those of the Neuse River estuary.

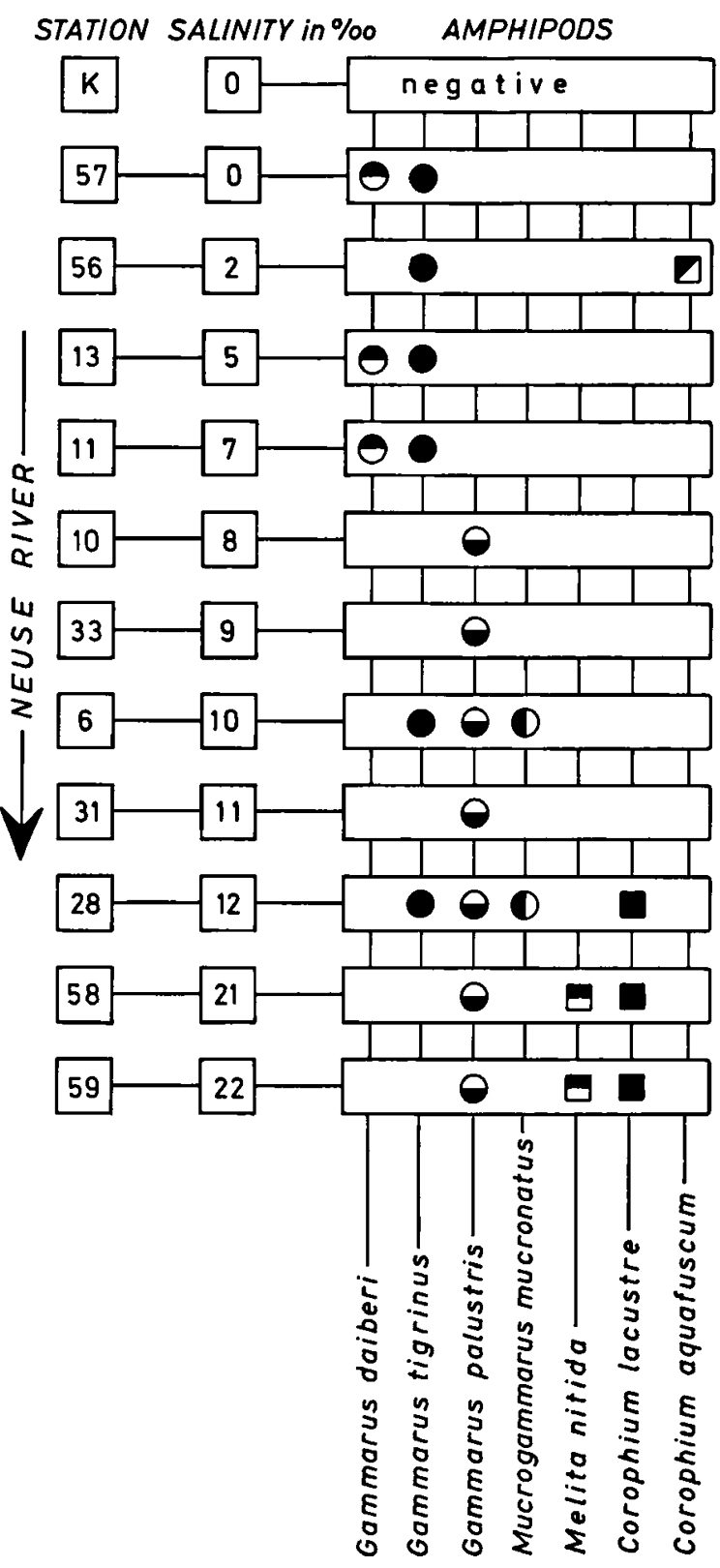

Fig. 1. Salinities and amphipods at the sampling stations in the Neuse River (station $K=$ Kinston).

In another tributary, the South River (discharging in the Neuse River about $50 \mathrm{~km}$ downstream of New Bern), Gammarus palustris Bousfield, 1969 , occurred at a salinity of $12 \%$ on and, together with Mucrogammarus mucronatus (Say, 1818), at a salinity of $18 \%$. 00 . These amphipods were captured amongst submerged parts of the riverbank vegetation, on a bottom consisting of clay and mud. 
Appendix I enumerates the amphipod species found during the present study, as well as the conditions at their sampling stations.

The following amphipods have been collected:

Family GAMMARIDAE (s.l.)

Gammarus tigrinus Sexton, 1939

Besides in the Neuse and Trent Rivers, Gammarus tigrinus was found in the White Oak River (fig. 2 ), discharging in the Bogue Sound near Swans- boro, and in the Bay River (sta. 61), a tributary of the Pamlico Sound. During the present investigation this species was sampled at salinities varying from 0 to $12 \%$ (only once it was found at $220 / 00$ ), always on sandy substrates, among roots of the River-cypress. In some localities $G$. tigrinus occurred together with other amphipods: In the Neuse River (figs. $1 \& 2$ ), near New Bern, together with Gammarus daiberi Bousfield, 1969 and Coropbium aquafuscum Heard \& Sikora,

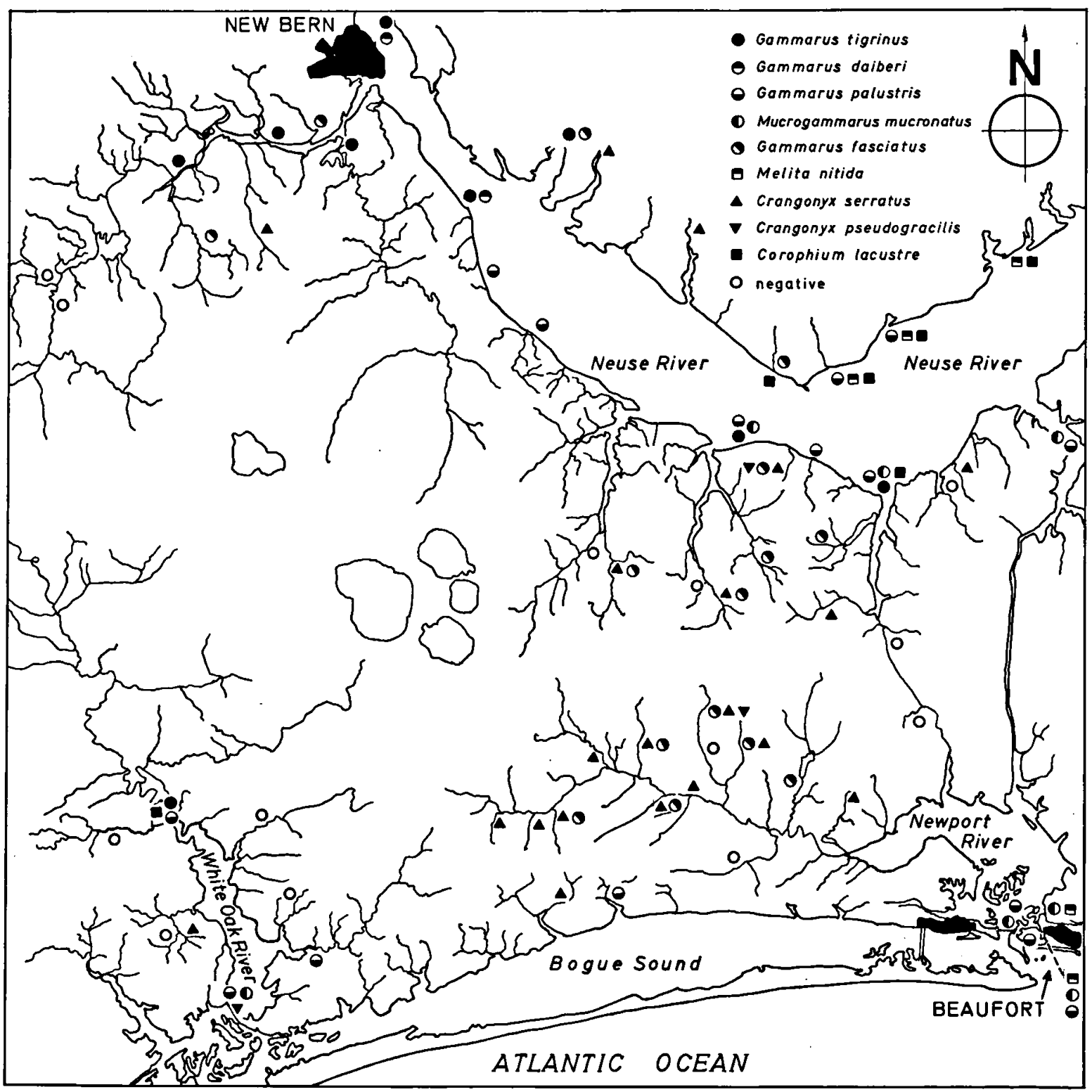

Fig. 2. Distribution of the amphipod species N.W. of Beaufort. 
1972 , at a salinity of $2 \%$; more downstream, at a salinity of $12 \%$, the sample contained also Coropbium lacustre Vanhöffen, 1911, Mucrogammarus mucronatus (Say, 1818) and Gammarus palustris Bousfield, 1969; near Cherry Point (sta. 6 ), the latter two occurred together with $G$. tigrinus at a salinity of $10 \%$; in the White Oak River, at a salinity of $1 \%$, only single specimens of $G$. palustris and $C$. lacustre were sampled together with $G$. tigrinus.

Ovigerous females of $G$. tigrinus occurred in a sample taken in June (salinity $10 \%$, temp. $25.5^{\circ} \mathrm{C}$ ).

Gammarus daiberi Bousfield, 1969

Gammarus daiberi, a species closely related to Gammarus tigrinus, occurred with the latter in the samples from the head of the Neuse River estuary, at salinities varying from 0 to $7 \%$ o .

\section{Gammarus fasciatus Say, 1818}

Gammarus fasciatus was collected mainly in moderately running streams and sometimes in slowly running or stagnant water. Water temperatures varied from 15.5 to $27^{\circ} \mathrm{C}$, the $\mathrm{pH}$ from 5.6 to 7.5 , and the salinity values in places where $G$. fasciatus occurred did not exceed 5\% freshwater streams or small marshy ponds (together with Crangonyx serratus (Embody, 1910)), varying in depth from $0.3 \mathrm{~m}$ to a few meters, among submerged parts of the marsh vegetation, on a sandy or muddy bottom.

In May and June ovigerous females of $G$. fasciatus have been observed.

\section{Gammarus palustris Bousfield, 1969}

Gammarus palustris ${ }^{2}$ ) is a very common species in the meso- and polyhaline waters around Beaufort. This gammarid, found at salinities of 8 to $360 \%$ (exceptionally at $10 \%$, vide supra), mostly occurred on a sandy substrate in the Spartina marshes or sometimes among marine algae (viz., Fucus vesiculosus, Ulva, Chaetomorpha). In

2) Dr. E. L. Bousfield informed me (in litt., 9 May 1978) that my "Gammarus palustris" material consists of two distinct species: true $G$. palustris, occurring at the higher salinities, and a new species of gammarid, the description of which is soon to be published by him. some places, devoid of such a vegetation, $G$. palustris was collected amongst oyster shells or tree roots.

While collecting, the present species was easily recognized by its particular behaviour: the shrimps climbed out of the water (in the vial) and were able to "rise to their feet", like beachhoppers (Talitridae) use to do.

Ovigerous females and/or precopulae were found from May to August.

\section{Mucrogammarus mucronatus (Say, 1818)}

Mucrogammarus mucronatus occurred sometimes, together with Gammarus palustris, in the Spartina marshes, but never at salinities lower than $10 \%$. On muddy substrates, mixed with cobbles and shells, the present gammarid was found together with Melita nitida Smith, 1873 (viz., the Towncreek at Beaufort). In that case the vegetation consisted of Ulva, Fucus vesiculosus or Chaetomorpha. The salinities measured for Mucrogammarus mucronatus varied from 10 to $32 \%$.

Ovigerous females of the present species occurred in a sample collected in May.

\section{Crangonyx serratus (Embody, 1910)}

Crangonyx serratus seems to prefer stagnant water of small marshy ponds, although it sometimes occurs in running water, not rarely together with Gammarus fasciatus. The salinities at stations with Cr. serratus varied from 0 to $5 \%$. When alive, the present amphipod shows a characteristic milky white colour.

In May ovigerous females of $\mathrm{Cr}$. serratus were observed.

\section{Crangonyx pseudogracilis Bousfield, 1958}

At two localities in freshwater biotopes, besides Gammarus fasciatus and Crangonyx serratus, Crangonyx pseudogracilis occurred among the marsh vegetation, on a bottom of sand and mud. Both samples, collected in May, contained ovigerous females.

Melita nitida Smith, 1873

Melita nitida was found mainly in the lower reaches of estuaries or in the tidal zone along the coast 
of the mainland of North Carolina. This amphipod was collected in muddy or sandy places, among marine algae (Fucus vesiculosus), in the Spartina marshes or under oyster shells. Downstream in the Neuse River estuary it occurred together with Gammarus palustris and Coropbium lacustre (fig. 1).

In May ovigerous females of the present species were found at a salinity of $32 \%$.

\section{Family COROPHIIDAE}

Corophium lacustre Vanhöffen, 1911

Coropbium lacustre was collected in the wavewashed zone of rivers, at salinities varying from 1 to $20 \%$ oo, on sandy substrates or in burrows in dead tree stumps.

In August ovigerous females were found.

Corophium aquafuscum Heard \& Sikora, 1972

Coropbium aquafuscum occurred in the Neuse River (upstream of New Bern) in stagnant water at a salinity of $2 \%$, the substrate consisting of sand, debris and tree roots.

Besides the sampling stations in the coastal plain of North Carolina, some waters more inland, near Chapell Hill, were visited, which yielded no amphipods, apart from a few specimens of Hyalella azteca De Saussure, 1857 (family Hyalellidae), collected in a dammed creek, called Hogans Pond (Orange County).

\section{DISCUSSION}

Fox \& Bynum (1975) mention Gammarus tigrinus to be very abundant in the oligohaline areas of the Neuse River. Boesch \& Diaz (1974) and Bousfield (1973) found the present species in the oligo- and mesohaline waters of upper Chesapeake Bay and its tributary estuaries. The results obtained during the present study extend the distribution of $G$. tigrinus southward into the headwaters of Pamlico Sound and Bogue Sound in North Carolina.

G. tigrinus shows a wide salinity range as has been demonstrated also by the experiments of Dorgelo $(1974,1975)$. Not only was it found at widely different salinities in North Carolina, it appeared to be very tolerant to high water temperatures as well $\left(34^{\circ} \mathrm{C}\right.$ during August!). According to Hynes (1955), G. tigrinus seems adapted to a climate with warm summers and springs characterized by a rapid rise in temperature. Such marine climatic conditions prevail along the coastal plain of North Carolina: in the Neuse River estuary a rapid rise in temperature takes place in early spring, while the water temperature attains rather high values during summer (fig. 3).

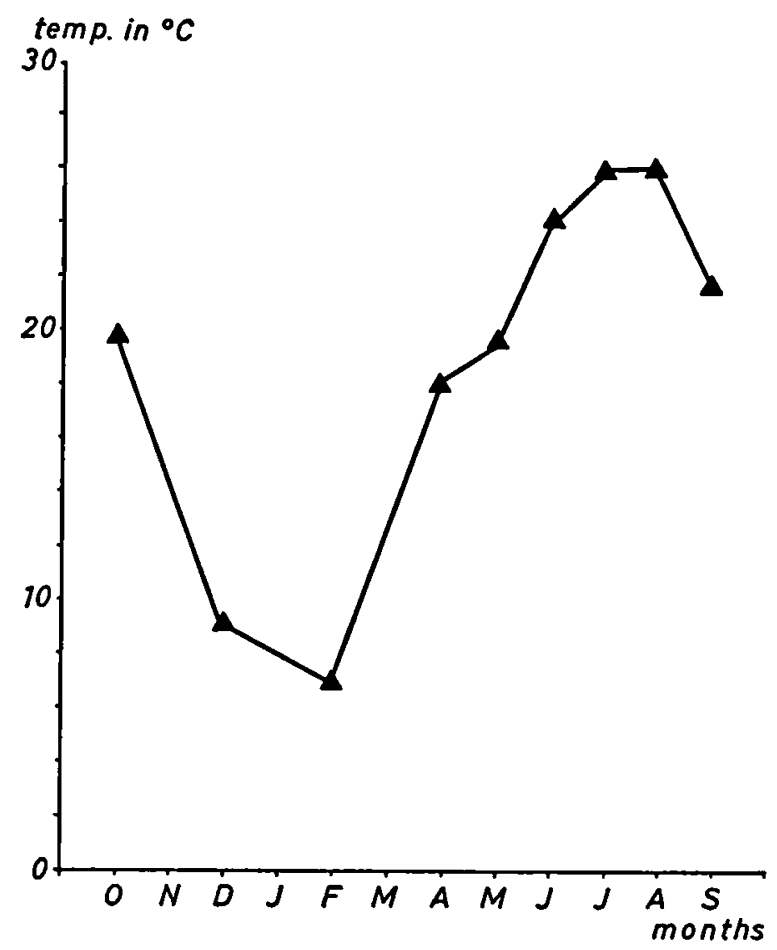

Fig. 3. Yearly temperature cycle in the Neuse River near New Bern (after data by Phibbs, 1969).

Steele \& Steele (1975) mention G. tigrinus to be more successful in the southern parts of the United States (more generations per year at higher temperatures), than in the North. Salinity preference experiments by Dorgelo (1975) proved that $G$. tigrinus is distinctly selective towards salinity at lower temperatures, while at a temperature of $25^{\circ} \mathrm{C}$ the results are very variable. According to Pinkster (1975), the ability of the present gammarid to reproduce at high temperatures, while salinity is reduced, explains its success in competing the indigenous gammarids in the Netherlands. Although the mixohaline species 
Gammarus zaddachi Sexton, 1912 and G. duebeni duebeni Liljeborg, 1852, can reproduce throughout the year provided that the salinity is high enough, they are unable to do so when the salinity drops to the level prevailing in most biotopes inhabited by $G$. tigrinus. Under suboptimal salinity conditions, G. zaddacbi and $G$.d.duebeni are only able to reproduce at low temperatures.

In North Carolina the salinities established for G. tigrinus vary from 0 to $12 \%$. The present species was found only in larger streams, often in stagnant or very slowly running waters. Never has it been found in smaller freshwater creeks, where $G$. fasciatus was commonly met. More downstream in estuaries $G$. tigrinus is replaced by G. palustris. A similar distribution pattern was established for $G$. tigrinus in the northern parts of the U.S.A. by Steele \& Steele (1972), where the distribution of this gammarid seems to be limited by the presence of $G$. fasciatus upstream, and seawards by $G$. lawrencianus Bousfield, 1956, a very common species in the tidal zone from Newfoundland to Connecticut. In view of the situation described above, it is interesting to see that in the Netherlands $G$. tigrinus does neither invade running fresh waters, where Gammarus pulex pulex (Linnaeus, 1758) thrives, nor waters of higher salinities in which it is apparently unable to compete with $G$. zaddachi and G. duebeni (Pinkster et al., 1977).

- Gammarus daiberi and Gammarus tigrinus resemble to such an extent that the former was only recently recognized as a distinct species. Although both gammarids can easily be recognized in the Delaware and Chesapeake region, material from the southeastern states shows overlapping of characters to a large degree (Bousfield, 1969). Thanks to the kindness of Dr. E. L. Bousfield to check the present samples of Gammarus tigrinus, the presence of Gammarus daiberi could be detected in the samples from the most upstream parts of the Neuse River estuary. It occurred together with $G$. tigrinus at salinities varying from 0 to $10 \%$. This is in agreement with the data of Ristich et al. (1977), who found G. tigrinus and $G$. fasciatus to be the most common amphipods in the freshwater zones of the Hudson River estuary, while in the oligo- and mesohaline reaches
$G$. tigrinus occurred together with $G$. daiberi. In the Delaware and Chesapeake Bays the latter species is most abundant in the head of the estuaries at salinities ranging from 1 to 5\% (Bousfield, 1969). According to Feeley \& Wass (1971) $G$. daiberi occupies the niche between $G$. fasciatus and the mesohaline $G$. tigrinus.

- Gammarus fasciatus was found to occur in the freshwater creeks discharging in the Neuse and Newport Rivers (fig. 2). According to Bousfield (1958) and Holsinger (1972) G. fasciatus lives in lakes as well as in large rivers, biotopes in which it was never observed in the Beaufort region.

- The occurrence of Gammarus palustris in the Spartina marshes of North Carolina was already recorcied by Fox \& Bynum (1975) and Cammen (1976). Also near its northern distribution limit, in New Hampshire, this gammarid was mentioned to occur in Spartina banks (Gable \& Croker, 1977). The observations concerning its presence among marine algae confirm the data by Watling \& Maurer (1972). The substrate preference experiments of Van Dolah (in press). who studied $G$. palustris from the salt marshes in the Chesapeake region, indicate a strong behavioural preference of this species for Spartina culms.

Bousfield (1973) records an optimal salinity range for $G$. palustris of 5-20\% that it is also able to survive, for shorter periods, in fresh water (at low temperatures) or in seawater (at high temperatures). During summer 1977 , it was found at salinities varying from $0 \%$ (temp. $20^{\circ} \mathrm{C}$ ) to $360 \%$ (temp. $30^{\circ} \mathrm{C}$ ). Although $G$. palustris occurred at very low salinities, it was never observed in permanent fresh water.

The semi-terrestrial behaviour of G. palustris, as observed during the present study, is in agreement with the observations by Bousfield (1973), who mentions it to remain hidden in moisty places (under stones, debris and among Spartina), when the tide is out.

- In agreement with the data by Watling \& Maurer (1972), Mucrogammarus mucronatus was found in the more sheltered places of the tidal zone.

On comparing M. mucronatus from the Beaufort region with specimens from Louisiana (in the 
collection of the Smithsonian Institution in Washington), the dorsal mucronations shown by the former animals are weakly developed, while those in the southern samples possess very pronounced dorsal elevations. Bousfield (1969) refers to $M$. mucronatus, originating from the coastal region of the southeastern states, as "micromucronate forms". Barnard \& Gray (1968) also mention the variation in development of the pleonal teeth in the present species and state that it might reflect variations in physical factors or genetic isolation. A similar variability of the dorsal processes is recorded by Karaman \& Pinkster (1977) for members of the Gammarus roeseli-group, which are, like $M$. $m u$ cronatus, characterized by the presence of dorsal mucronations on the metasome segments.

- Embody (1910), describing Crangonyx serratus for the first time, mentions it from a pond in Virginia. Bousfield (1958) indicates its occurrence in sloughs, ponds and ditches in Virginia, South Carolina and northern Florida. During the present investigation $C r$. serratus was not only found in stagnant water, but has been observed in slowly and moderately running waters as well.

- In addition, Crangonyx pseudogracilis was found to occur in North Carolina. Holsinger (1972) supposed it to occur as far south as the Mississippi stream system, but remarks that $C r$. pseudogracilis might be a complex of, very closely related, but different species.

- In agreement with the present results, Watling \& Maurer (1972) found Melita nitida in polyhaline and marine localities, under oyster shells, a habitat mentioned also by Thomas (1976) for this species, in Louisiana.

- In the lower reaches of the Neuse River estuary, Corophium lacustre was commonly met. According to Bousfield (1973) this amphipod occurs from almost fresh water up to salinities as high as $25 \%$. Although mostly encountered in mesohaline waters, during the present study $C$. lacustre was found once at a salinity of $10 \%$, upstream in the White Oak River estuary (fig. 2).

- Corophium aquafuscum, found during the present study in the Neuse River, upstream of New Bern, at a salinity of $2 \%$, was recorded earlier from a nearby locality by Bynum \& Fox (1977). They collected this amphipod under freshwater conditions, the vegetation consisting of River. cypress and Spartina.

\section{ACKNOWLEDGEMENTS}

I am indebted to the Netherlands' Organization for the Advancement of Pure Research (Z.W.O.) for providing me with a grant, which has allowed me to carry out the present study during the months of May, June and July 1977, as well as to the Duke University (Durham, North Carolina) for a travel grant during August. Furthermore I owe many thanks to Prof. John D. Costlow, director of the Duke Marine Laboratory, for receiving me in his laboratory and putting the facilities of the biological station at my disposal. I want to express my gratitude as well to Dr. J. L. Barnard for allowing me to work some days in his laboratory with the amphipod samples of the collection of the Smithsonian Institution at my disposal. I am also grateful to Prof. J. H. Stock, Drs. F. Peeters-Pieters and Dr. S. Pinkster for their critical comments on the manuscript of this paper; and to Mr. J. Zaagman for his assistance in making the figures.

Special thanks are due to Dr. E. L. Bousfield of the Museum of Natural Sciences, Ottawa, for checking a number of my samples and for reviewing the manuscript of the present paper.

\section{REFERENCES}

BARNARd, J. L. \& W. S. GRAY, 1968. Introduction of an amphipod crustacean into the Salton Sea. Bull. Sth. Calif. Acad. Sci., 67 (4): 219-232.

BOEsCH, D. F. \& R. J. Diaz, 1974. New records of pericarid crustaceans from oligohaline waters of the Chesapeake Bay. Chesapeake Sci., 15 (1): 56-59.

BOUSFIELD, E. L., 1958. Fresh-water amphipod crustaceans of glaciated North-America. Can. Fld. Nat., 72 (2): 55.113.

- 1969. New records of Gammarus (Crustacea: Amphipoda) from the Middle Atlantic Region. Chesapeake Sci., 10 (1): 1-17.

- 1973. Shallow-water gammaridean Amphipoda of New England: i-xii, 1.312 (Cornell Univ. Press, Ithaca, N.Y.).

ByNum, K. H. \& R. S. Fox, 1977. New and noteworthy amphipod crustaceans from North Carolina, U.S.A. Chesapeake Sci., 18 (1): 1-33.

Cammen, L. M., 1976. Abundance and production of macroinvertebrates from natural and artificially established salt marshes in North Carolina. Am. Midl. Nat., 96 (2): 487-493.

Dennert, H. G., A. L. Dennert \& J. H. Stock, 1968. Range extension in 1967 of the alien amphipod Gammarus tigrinus Sexton, 1939, in the Netherlands. Bull. zool. Mus. Univ. Amsterdam, 1 (7): 79-80.

Dieleman, J. \& S. Pinkster, 1977. Further observations on the range extension of the alien amphipod Gammarus tigrinus Sexton, 1939, in the Netherlands during the years 1974 to 1976. Bull. zool. Mus. Univ. Amsterdam, 6 (3): 21-29.

Dorgelo, J., 1974. Comparative ecophysiology of gammarids (Crustacea, Amphipoda) from marine, brackish and fresh-water habitats, exposed to the influence of salinitytemperature combinations, I. Effect on survival. Hydrobiol. Bull., 8 (1-2): 90-108.

, 1975. Comparative ecophysiology of gammarids (Crus- 
tacea, Amphipoda) from marine, brackish and freshwater habitats, exposed to the influence of salinitytemperature combinations, II. Preference experiments. Verh. int. Verein. theor. angew. Limnol., 19: 3007-3013. EмвоDY, G. C., 1910. A new fresh-water amphipod from Virginia with some notes on its biology. Proc. U.S. natn. Mus., 38: 299-305.

FeELEY, J. B. \& M. L. WASs, 1971. The distribution and ecology of the Gammaridea (Crustacea: Amphipoda) of the lower Chesapeake estuaries. Virginia Inst. mar. Sci., Spec. Pap. mar. Sci., 2: 1-58.

Fox, R. S. \& K. H. Bynum, 1975. The amphipod crustaceans of North-Carolina estuarine waters. Chesapeake Sci., 16 (4): 223-237.

Gable, M. F. \& R. A. CROKeR, 1977. The salt marsh amphipod Gammarus palustris Bousfield, 1969 at the northern limit of its distribution, I. Ecology and life cycle. Estuar. cst. mar. Sci., 5: 123-134.

Gras, J. M. J. F., 1971. Range extension in the period 19681970 of the alien amphipod Gammarus tigrinus Sexton, 1939, in the Netherlands. Bull. zool. Mus. Univ. Amsterdam, 2 (2): 5-9.

Holsinger, J. R., 1972. The freshwater amphipod crustaceans (Gammaridae) of North-America. Biota of freshwater ecosystems. U.S. Environmental Protection Agency, Identification Manual, 5: 1-89.

HyNes, H. B. N., 1955. The reproductive cycle of some British freshwater Gammaridae. J. anim. Ecol., 24 (2): 352-387.

Karaman, G. S. \& S. Pinkster, 1977. Freshwater Gammarus species from Europe, North Africa and adjacent regions of Asia (Crustacea, Amphipoda). Part II. Gammarus roeseli-group and related species. Bijdr. Dierk., 47 (2): 165-196.

NiJSSEN, H. \& J. H. STock, 1966. The amphipod Gammarus tigrinus Sexton, 1939, introduced in the Netherlands (Crustacea). Beaufortia, 13 (160): 197-206.

Phibbs, E. J., 1969. Chemical and physical character of surface waters of North Carolina, 1966-1967. Bull. Wat. Pollut. Control Div., N. Carol. Dep. Wat. Air Resour., 11 (1): 83.
Pinkster, S., 1975. The introduction of the alien amphipod Gammarus tigrinus Sexton, 1939 (Crustacea, Amphipoda), in the Netherlands and its competition with indigenous species. Hydrobiol. Bull., 9 (3): 131-138.

Pinkster, S. \& J. H. Stock, 1967. Range extension of the alien amphipod Gammarus tigrinus Sexton, 1939, in the Netherlands. Beaufortia, 14 (169): 81-86.

Pinkster, S., H. Smit \& N. Brandse-de Jong, 1977. The introduction of the alien amphipod Gammarus tigrinus Sexton, 1939, in the Netherlands and its competition with indigenous species. Crustaceana, Suppl. 4: 91-105.

Ristich, S. S., M. Crandall \& J. Fortier, 1977. Benthic and epibenthic macroinvertebrates of the Hudson River, I. Distribution, natural history and community structure. Estuar. cst. mar. Sci., 5: 255-266.

Sexton, E. W., 1939. On a new species of Gammarus (G. tigrinus) from Droitwich district, with an appendix by L. H. N. CoOper. J. mar. biol. Ass. U.K., 23: 543-551, pls. IV-VI.

SMIT, H., 1974. Extension de l'aire de répartition de Gammarus tigrinus Sexton en 1973 aux Pays Bas, et quelques remarques sur la concurrence avec les gammares indigènes (Crustacea, Amphipoda). Bull. zool. Mus. Univ. Amsterdam, 4 (5): 35.44.

Steele, D. H. \& V. J. Steele, 1972. The biology of Gammarus (Crustacea, Amphipoda) in the northwestern Atlantic, VI. Gammarus tigrinus Sexton. Can. J. Zool., 50 (8): 1063-1068.

— \& - 1975. The biology of Gammarus (Crustacea, Amphipoda) in the northwestern Atlantic, XI. Comparison and discussion. Can. J. Zool., 53 (8): 1116-1126.

ThомAs, J. D., 1976. A survey of gammarid amphipods of Barataria Bay, Louisiana Region. Contr. mar. Sci., 20: 87-100.

VAN Dolah, R. F., in press. Factors regulating the distribution and population dynamics of the amphipod Gammarus palustris in an intertidal salt marsh community. Ecol. Monogr.

Watling, L. \& D. MaureR, 1972. Marine shallow water amphipods of the Delaware Bay area, U.S.A. Crustaceana, Suppl. 3: 251-266.

\section{APPENDIX I}

Amphipod species and environmental conditions at the sampling stations visited near Beaufort (the position of these stations is given in appendix II).

\section{(A) GAMMARUS TIGRINUS}

\begin{tabular}{|c|c|c|c|c|c|c|}
\hline Station & $\begin{array}{l}\text { Temp. } \\
\left({ }^{\circ} \mathrm{C}\right)\end{array}$ & $\mathrm{pH}$ & $\begin{array}{l}\text { Salinity } \\
(0 / 00)\end{array}$ & Substrate & Vegetation & Remarks \\
\hline 6 & 30 & & 10 & sand + wood & Chaetomorpha & among tree roots and in wood b \\
\hline 11 & 18.5 & 7.1 & 7 & sand + shells + wood & - & in wave-washed zone; among tre \\
\hline 12 & 22 & 7.1 & 5 & sand + detritus & riverbank vegetation & few gammarids \\
\hline 13 & 23 & 6.9 & 5 & sand + wood & - & in wave-washed zone; among $t$ \\
\hline 28 & 24 & 7.1 & 12 & sand + clay & Spartina & in wave-washed zone \\
\hline 34 & 25.5 & 6.8 & 1 & mud + detritus & Sagittaria & $\begin{array}{l}\text { slowly running brown water; ovi } \\
\uparrow \uparrow\end{array}$ \\
\hline 37 & 24 & 7.1 & 2 & clay + detritus & riverbank vegetation & \\
\hline 46 & 26.5 & 6.5 & 1 & sand + detritus & riverbank vegetation & \\
\hline 56 & 34 & 6.3 & 2 & sand + detritus + wood & riverbank vegetation & stagnant water; among tree roots \\
\hline 57 & 29.5 & 7.2 & 0 & sand + wood & - & slowly running water; precopulae \\
\hline 61 & 33 & 7.8 & 22 & mud + detritus & riverbank vegetation & very few gammarids \\
\hline
\end{tabular}




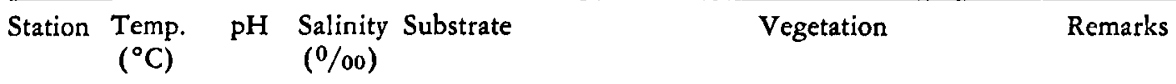

(B) GAMMARUS DAIBERI

$\begin{array}{rlrrl}11 & 18.5 & 7.1 & 7 & \text { sand + shells + wood } \\ 13 & 23 & 6.9 & 5 & \text { sand + wood } \\ 57 & 29.5 & 7.2 & 0 & \text { sand + wood } \\ 61 & 33 & 7.8 & 22 & \text { mud + detritus }\end{array}$

\section{(C) GAMMARUS FASCIATUS}

\begin{tabular}{lllll}
14 & 18.5 & 6.9 & 0 & mud \\
20 & 15.5 & 7.5 & 0 & sand + detritus + wood \\
21 & & 7.4 & 0 & sand + mud \\
& & & & \\
22 & 15 & 6.8 & 0 & sand + mud \\
& & & & \\
23 & & 7.1 & 0 & sand + detritus \\
27 & 20 & 6.8 & 0 & sand + mud \\
\hline 29 & 21 & 7.0 & 0 & mud \\
30 & 20.5 & 6.9 & 1 & sand + mud \\
\hline 32 & 22.5 & 6.7 & 1 & mud + detritus \\
36 & 20 & 6.5 & 1 & sand + mud \\
38 & 20 & 7.2 & 0.5 & clay \\
& & & & \\
39 & 18.5 & 6.9 & 5 & sand + detritus \\
\hline 43 & 23 & 6.6 & 0.5 & sand \\
\hline $52 b$ & 25 & 6.6 & 0 & sand + shells \\
55 & 27 & 5.6 & 0 & mud
\end{tabular}

\section{(D) GAMMARUS PALUSTRIS}

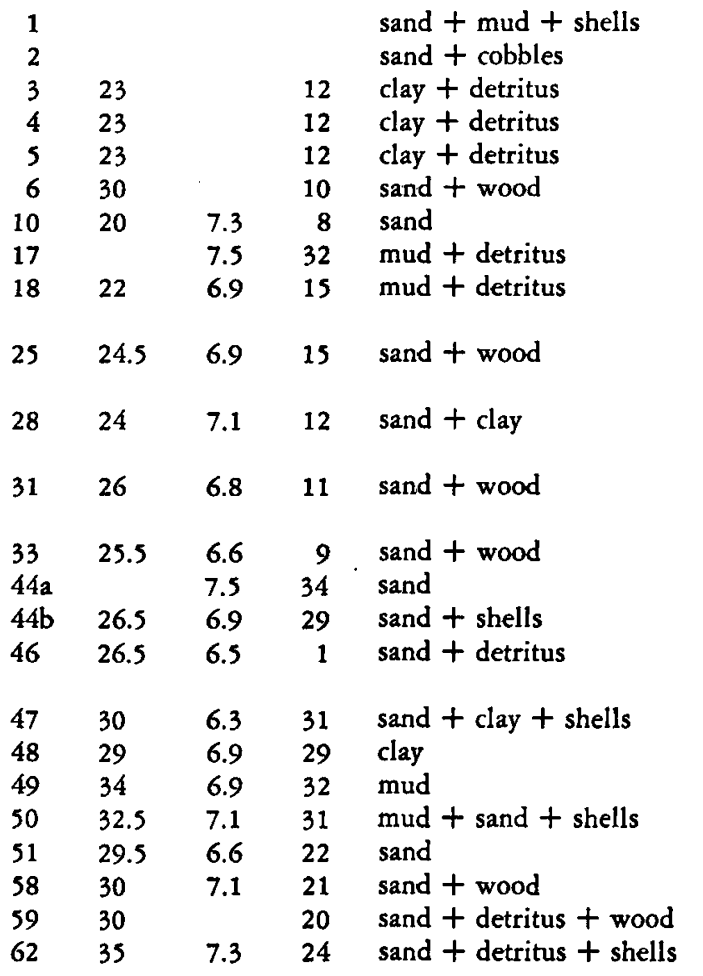

$\frac{-}{-}$

riverbank vegetation

riverbank vegetation

marsh vegetation

marsh vegetation

marsh vegetation

marsh vegetation

marsh vegetation

riverbank vegetation

marsh vegetation

marsh vegetation

marsh vegetation

\section{Fucus vesiculosus}

Ulva

riverbank vegetation riverbank vegetation Chaetomorpha Chaetomorpha riverbank vegetation Spartina

Spartina

Spartina

\section{Spartina}

Spartina

riverbank vegetation

\section{Spartina}

Spartina, Salicornia

Spartina

Ulva

Spartina

Spartina in wave-washed zone; among tree roots in wave-washed zone; among tree roots slowly running water very few gammarids

stagnant brown water; ovigerous $ㅇ$ moderately running water; ovigerous 우 우

moderately running water; ovigerous 우 9

moderately running water; ovigerous 우

slowly running water

moderately running water; ovigerous 오 우

slowly running water

stagnant water; precopulae and ovigerous 우

slowly running water

moderately running brown water

moderately running water; many gammarids; precopulae and ovigerous $\$ ?$ moderately running water; precopulae and ovigerous $\% ?$

moderately running brown water; precopulae

moderately running water moderately running water

under shells, on rather dry substrate under cobbles

moderately running water

slowly running water; precopulae slowly running water

in wave-washed zone; among tree roots in wave-washed zone; precopulae slowly running water; precopulae slowly running water; very few gam. marids

in wave-washed zone; among tree roots; ovigerous 우 우

in wave-washed zone; precopulae and ovigerous $9 \%$

in wave-washed zone; among tree roots and other wood

in wave-washed zone; among wood stagnant water; precopulae

very few gammarids; slowly running water

in wave-washed zone; precopulae

stagnant water

stagnant water

stagnant water

slowly running water

among tree roots

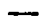

stagnant water; precopulae 


\begin{tabular}{|c|c|c|c|c|c|c|}
\hline Station & $\begin{array}{l}\text { Temp. } \\
\left({ }^{\circ} \mathrm{C}\right)\end{array}$ & $\mathrm{pH}$ & $\begin{array}{l}\text { Salinity } \\
(0 / 00)\end{array}$ & Substrate & Vegetation & Remarks \\
\hline 63 & 30 & 7.7 & 36 & sand & Spartina & precopulae \\
\hline 64 & 29.5 & 7.8 & 18 & sand & Spartina & precopulae and ovigerous $\$$ 웅 \\
\hline \multicolumn{7}{|c|}{ (E) MUCROGAMMARUS MUCRONATUS } \\
\hline 1 & & & & sand + mud + shells & Fucus vesiculosus & under shells, on a rather dry substrate \\
\hline 2 & & & & sand + cobbles & Ulva & under cobbles \\
\hline 5 & 23 & & 12 & clay + detritus & Chaetomorpha & slowly running water \\
\hline 6 & 30 & & 10 & sand + wood & Chaetomorpha & $\begin{array}{l}\text { in wave-washed zone, among tree roots; } \\
\text { ovigerous } 9 \%\end{array}$ \\
\hline 7 & & & 32 & sand + clay + shells & Ulva & under oyster shells \\
\hline 25 & 24.5 & 6.9 & 15 & sand + wood & $\cdot$ & in wave-washed zone, among tree roots \\
\hline 28 & 24 & 7.1 & 12 & sand + clay & Spartina & in wave-washed zone \\
\hline $44 \mathrm{~b}$ & 26.5 & 6.9 & 29 & sand + shells & Spartina & - \\
\hline 47 & 30 & 6.3 & 31 & sand + clay + shells & Spartina & in wave-washed zone \\
\hline 49 & 34 & 6.9 & 32 & mud & Spartina & stagnant water \\
\hline 50 & 32.5 & 7.1 & 31 & mud + sand + shells & Ulva & stagnant water \\
\hline
\end{tabular}

(F) CRANGONYX SERRATUS

$\begin{array}{rllll}8 & 16 & 6.7 & 1 & \text { clay + detritus } \\ 15 & & 7.2 & 0 & \text { mud } \\ 19 & 15.5 & 7.1 & 0 & \text { mud + detritus } \\ 20 & 15.5 & 7.5 & 0 & \text { sand + detritus + wood } \\ 22 & 15 & 6.8 & 0 & \text { sand + mud } \\ 24 & & 6.8 & 0 & \text { mud + detritus } \\ 26 & 21 & 6.9 & 0 & \text { mud + detritus } \\ 29 & 21 & 7.0 & 0 & \text { mud } \\ 30 & 20.5 & 6.9 & 1 & \text { sand + mud } \\ 32 & 22.5 & 6.7 & 1 & \text { mud + detritus } \\ 35 & 21 & 6.9 & 1 & \text { clay + detritus } \\ 39 & 18.5 & 6.9 & 5 & \text { sand + detritus } \\ 40 & 19.5 & 6.6 & 0.5 & \text { mud + detritus } \\ 41 & 20 & 6.2 & 1 & \text { sand + mud + detritus } \\ 42 & 20 & 6.9 & 1 & \text { sand } \\ 43 & 23 & 6.6 & 0.5 & \text { sand } \\ 45 & 21 & 6.9 & 1 & \text { mud } \\ 53 & 27 & 5.9 & 0.5 & \text { mud } \\ 54 & 27 & 5.6 & 1 & \text { mud } \\ 55 & 27 & 5.6 & 0 & \text { mud }\end{array}$

(G) CRANGONYX PSEUDOGRACILIS

$\begin{array}{ccccc}22 & 15 & 6.8 & 0 & \text { sand + mud } \\ 30 & 20.5 & 6.9 & 1 & \text { sand + mud }\end{array}$

(H) MELITA NITIDA

$\begin{array}{lllll}1 & & & & \text { sand + mud + shells } \\ 7 & & & 32 & \begin{array}{l}\text { sand + clay + shells } \\ \text { s4b }\end{array} \\ 46.5 & 6.9 & 29 & \text { sand + shells } \\ 47 & 30 & 6.3 & 31 & \text { sand + clay + shells } \\ 50 & 32.5 & 7.1 & 31 & \text { sand + clay + shells } \\ 58 & 30 & 7.1 & 21 & \text { sand + wood } \\ 59 & 30 & & 20 & \text { sand + cobbles + shells } \\ 60 & 33 & 6.9 & 20 & \text { sand + mud + wood } \\ 62 & 35 & 7.3 & 24 & \text { sand + detritus + shells }\end{array}$

(I) COROPHIUM LACUSTRE

$\begin{array}{llrrl}28 & 24 & 7.1 & 12 & \text { sand + clay } \\ 46 & 26.5 & 6.5 & 1 & \text { sand + detritus } \\ 52 a & 31 & 6.4 & 11 & \text { sand + shells + wood } \\ 58 & 30 & 7.1 & 21 & \text { sand + wood } \\ 59 & 30 & & 20 & \text { sand + cobbles + wood } \\ 60 & 33 & 6.9 & 20 & \text { sand + mud + wood }\end{array}$

(J) COROPHIUM AQUAFUSCUM

$\begin{array}{lllll}56 & 34 & 6.3 & 2 & \text { sand + detritus + wood }\end{array}$ marsh vegetation marsh vegetation -

marsh vegetation

marsh vegetation marsh vegetation marsh vegetation marsh vegetation Sagittaria

riverbank vegetation

riverbank vegetation marsh vegetation marsh vegetation marsh vegetation

marsh vegetation

marsh vegetation

marsh vegetation

Fucus vesiculosus Ulva

Spartina

Spartina

Ulva

Spartina

—

Spartina

-
Spartina
-

riverbank vegetation stagnant brown water; ovigerous $ㅇ$

stagnant water; ovigerous $q$ 우

moderately running water

moderately running water

stagnant water

stagnant, muddy water

slowly running water

stagnant water

slowly running water

slowly running water

moderately running water

stagnant water

stagnant water

moderately running water

moderately running water

moderately running water

stagnant water; few gammarids

moderately running water

moderately running water

moderately running water; ovigerous

$\% ?$

stagnant water

under shells, on a rather dry substrate under oyster shells; ovigerous $q$ 우

in wave-washed zone

stagnant water

in wave-washed zone

in wave-washed zone

stagnant water; few gammarids

in wave-washed zone

slowly running water

in wave-washed zone

in wave-washed zone

in wave-washed zone; ovigerous $\$ ?$

in wave-washed zone; ovigerous $\$ ?$ 


\section{APPENDIX II}

Position of the sampling stations as mentioned in fig. 1 and appendix I. The stations marked with an asterisk are not included in the map (fig. 2).

\begin{tabular}{|c|c|c|c|}
\hline Station & $\begin{array}{l}\text { Date } \\
(1977)\end{array}$ & Position & County \\
\hline 1 & $3-\mathrm{V}$ & Beaufort, beach E. of bridge near Pivers Island & Carteret \\
\hline 2 & $3-\mathrm{V}$ & Newport River, left bank upstream of bridge on highway 70 & Carteret \\
\hline *3 & $4-\mathrm{V}$ & South River, left bank near village South River & Carteret \\
\hline *4 & $4-\mathrm{V}$ & South River, right bank & Carteret \\
\hline *5 & $4-\mathrm{V}$ & South River, left bank, about $50 \mathrm{~m}$ downstream of jetty of D.U.M.L. boat & Carteret \\
\hline 6 & S-V & Neuse River, right bank upstream of landing stage of Cherry Point ferry & Carteret \\
\hline 7 & $8-\mathrm{V}$ & Beaufort, Towncreek, midway bridge and town & Carteret \\
\hline 8 & $10-\mathrm{V}$ & tributary of Newport River, Newport, near bridge on highway 70 & Carteret \\
\hline 9 & $10 \cdot \mathrm{V}$ & Southwest Prong, N.W. of Havelock, highway 70 & Craven \\
\hline 10 & $10-\mathrm{V}$ & Neuse River, right bank near Fisher Landing, N.E. of Riverdale & Craven \\
\hline 11 & $10-\mathrm{V}$ & Neuse River, right bank near Thurman, S.E. of New Bern & Craven \\
\hline 12 & $10-\mathrm{V}$ & Trent River, left bank, S.W. of New Bern & Craven \\
\hline 13 & $10-\mathrm{V}$ & Neuse River, left bank, upstream of bridge near New Bern & Craven \\
\hline 14 & $10-\mathrm{V}$ & Cahooque Creek, E. of Havelock, near bridge on road to Cherry Point & Craven \\
\hline 15 & $10-\mathrm{V}$ & Mortons Mill Pond, N.W. of Harlowe, near bridge on highway 101 & Craven \\
\hline 16 & $10-\mathrm{V}$ & Harlowe Creek, near Harlowe Church, N. of Morehead City & Carteret \\
\hline 17 & $13 \cdot V$ & Gale Creek, Bogue Sound, upstream of bridge on highway 24 & Carteret \\
\hline 18 & $13-\mathrm{V}$ & Pettiford Creek, N.E. of Swansboro, upstream of bridge on highway 58 & Carteret \\
\hline 19 & $13-V$ & small stream discharging in Broad Creek (Knoll) near bridge on highway 1124 & Carteret \\
\hline 20 & $15-\mathrm{V}$ & Cedar Swamp, W. of Newport, near bridge on highway 1140 (Roberts Road) & Carteret \\
\hline 21 & $17-\mathrm{V}$ & Little Deep Creek near Union Point, N.E. of Newport & Carteret \\
\hline 22 & $17 \cdot \mathrm{V}$ & Deep Creek, N. of Newport, near bridge on loop road & Carteret \\
\hline 23 & $17-\mathrm{V}$ & Black Creek near Mill Pond, E. of Newport, near bridge on highway 1154 & Carteret \\
\hline 24 & $17-\mathrm{V}$ & Little Creek Swamp, E. of Newport, near bridge on highway 1154 & Carteret \\
\hline 25 & $20-\mathrm{V}$ & Adams Creek, left bank, where road from Harlowe ends in Great Neck & Craven \\
\hline 26 & $20-\mathrm{V}$ & Great Neck Creek, S.W. of Type & Craven \\
\hline 27 & $25-\mathrm{V}$ & Mitchell Creek, near Piney Grove Church, bridge on highway 1711 & Craven \\
\hline 28 & $25-\mathrm{V}$ & Neuse River, right bank, near Temple, mouth of Clubfoot Creek & Craven \\
\hline 29 & $25-\mathrm{V}$ & Hancock Creek, E. of Havelock, near bridge on highway 101 (New Bern Road) & Craven \\
\hline 30 & $31-\mathrm{V}$ & small stream discharging in Neuse River, near Cherry Point & Craven \\
\hline 31 & $31-\mathrm{V}$ & $\begin{array}{l}\text { Neuse River, right bank, near Shade View Beach, downstream of Neuse River } \\
\text { ferry }\end{array}$ & Craven \\
\hline 32 & $31-\mathrm{V}$ & East Prong near Havelock, highway 101 & Craven \\
\hline 33 & 3-VI & $\begin{array}{l}\text { Neuse River, right bank, Flanner Beach, near camping ground of Croatan } \\
\text { National Forest }\end{array}$ & Craven \\
\hline 34 & 3-VI & Brice Lees Brook, near Trent River, S.W. of New Bern & Craven \\
\hline 35 & 3-VI & Ready Brook, near bridge on highway 1004, S.W. of New Bern & Craven/Jones \\
\hline 36 & 3-VI & $\begin{array}{l}\text { Island Creek, N.E. of Pollocksville, near bridge on highway } 1004 \text { (Island Creek } \\
\text { Road) }\end{array}$ & Jones \\
\hline 37 & 3.VI & Trent River, near Mussy Cove, midway Pollncksville and New Bern & Craven/Jones \\
\hline 38 & 3.VI & small stream on left bank of Trent River, S.W. of New Bern & Craven \\
\hline 39 & 8-VI & Jason Brook, W. of Newport, near bridge on by-way (dirt road) of highway 1124 & Carteret \\
\hline 40 & 8-VI & $\begin{array}{l}\text { Peak Swamp, W. of Newport, near bridge on by-way (dirt road 128) of } \\
\text { highway } 1124\end{array}$ & Carteret \\
\hline 41 & 8-VI & $\begin{array}{l}\text { Mills Swamp, W. of Newport, near bridge on by-way (dirt road 128) of } \\
\text { highway } 1124\end{array}$ & Carteret \\
\hline 42 & 8.VI & Northwest Prong near Holly Springs, N.W. of Newport, bridge on highway 1124 & Carteret \\
\hline 43 & 8-VI & small stream near Masontown, N.W. of Newport & Carteret \\
\hline $44 a$ & $10-\mathrm{VI}$ & beach midway Beaufort and Morehead City & Carteret \\
\hline $44 \mathrm{~b}$ & 15.VI & White Oak River, right bank, near Swansboro, bridge on highway 24 & Onslow \\
\hline 45 & 15.VI & Holland Mill Creek, tributary, N.W. of Swansboro & Onslow \\
\hline 46 & 15-VI & White Oak River, near Stella & Onslow/Carteret \\
\hline *47 & 20-VI & North River, N.E. of Beaufort, bridge on highway 70 & Carteret \\
\hline$* 48$ & 20-VI & North River, near Otway, bridge on highway 70 & Carteret \\
\hline *49 & 20-VI & Core Sound, near Smyrna & Carteret \\
\hline *50 & 20-VI & Core Sound, near bridge on highway 70 , midway Williston and Davis & Carteret \\
\hline
\end{tabular}




\begin{tabular}{|c|c|c|c|}
\hline Station & $\begin{array}{l}\text { Date } \\
(1977)\end{array}$ & Position & County \\
\hline *51 & 20-VI & $\begin{array}{l}\text { water in between Cedar Island and the mainland, connecting Long Bay and } \\
\text { Core Sound }\end{array}$ & Carteret \\
\hline $52 a$ & 13-VII & Neuse River, left bank, near Arapahoe, Bennett Road, "Minnesott Manor" & Pamlico \\
\hline $52 \mathrm{~b}$ & 13-VII & small stream discharging in Neuse River near station 52a & Pamlico \\
\hline 53 & 13-VII & $\begin{array}{l}\text { Beard Creek, discharging in Neuse River, across Cherry Point U.S. Naval } \\
\text { Reservation }\end{array}$ & Pamlico \\
\hline 54 & 13-VII & Goose Creek, Reelsboro Fire district, S.E. of New Bern & Pamlico \\
\hline 55 & 13-VII & Upper Broad Creek, Tricommunity Fire district & Pamlico \\
\hline *56 & 13-VII & Neuse River, right bank, upstream of New Bern, "Gap Landing" & Craven \\
\hline *57 & 3-VIII & Neuse River, near Askin, N.W. of New Bern & Craven \\
\hline 58 & 9-VIII & $\begin{array}{l}\text { Neuse River, left bank, midway Minnesott and Janeiro, downstream of Camp } \\
\text { Don Lee }\end{array}$ & Pamlico \\
\hline 59 & 9-VIII & Neuse River, left bank, near Janeiro, bridge of tributary & Pamlico \\
\hline 60 & 9-VIHI & Neuse River, left bank, near Oriental, Robert Scott bridge & Pamlico \\
\hline *61 & 9-VIII & Bay River, near Stonewall, bridge on highway 55 & Pamlico \\
\hline *62 & 9-VIII & Bay River, left bank, near Vandemere, N.E. of Bayboro, highway 304 & Pamlico \\
\hline 63 & $11-$ VIII & Newport River, upstream of bridge on highway 70 , Morehead City & Carteret \\
\hline 64 & 22-VIII & South River, near village South River, downstream of jetty of D.U.M.L. boat & Carteret \\
\hline
\end{tabular}

Received: 8 March 1978 